\title{
UDC 621.833
}

P. Tkach $^{1}, \mathrm{PhD}$, Assoc. Prof.,

P. Nosko ${ }^{2}$, DSc, Prof.,

O. Bashta ${ }^{2}, \mathrm{PhD}$, Assoc. Prof.,

Yu. Tsybrii ${ }^{2}, \mathrm{PhD}$,

O. Revyakina ${ }^{3}$, PhD, Assoc. Prof.,

G. Boyko ${ }^{4}$, PhD, Assoc. Prof.

${ }^{1}$ E.O. Paton Electric Welding Institute of the National Academy of Sciences of Ukraine, 11 Kazymyr Malevych Str., Kyiv, Ukraine, 03150; e-mail: pavlotkach78@gmail.com

${ }^{2}$ National Aviation University, 1 Kosmonavta Komarova Ave., Kyiv, Ukraine, 03058

${ }^{3}$ Taras Shevchenko Lugans'k National University, 1 Gogol Square, Starobilsk, Ukraine, 92703

${ }^{4}$ Volodymyr Dahl East Ukrainian National University, 59-a Tsentralny Ave., Severodonets'k, Ukraine, 93400

\section{COMPARISON OF SINUSOIDAL AND INVOLUTE SPUR GEARS BY MESHING CHARACTERISTICS}

П.М. Ткач, П.Л. Носко, О.В. Башта, Ю.О. Цибрій, О.О. Ревякіна, Г.О. Бойко. Порівняння синусоїдального та евольвентного прямозубих зачеплень за якісними показниками. Стаття присвячена актуальному завданню створення зачеплень, які є альтернативними до евольвентного (традиційного), та можуть бути застосовані в силових приводах машин. Найпоширенішою вимогою до альтернативних видів зачеплень є більша у порівнянні з традиційним навантажувальна здатність та довговічність. Для забезпечення зазначеної вимоги може бути використано синусоїдальне зачеплення. Метою даної роботи $\epsilon$ встановлення його переваг у порівнянні $з$ традиційною передачею. Для досягнення мети було виконано теоретичне дослідження якісних показників працездатності, які відносяться до трьох рівнів - одиничні, комплексні та інтегральний. Для зубчастих зачеплень якісними показниками $є$ швидкість ковзання, швидкість руху точок контакту у напрямку, нормальному до контактної лінії, відносні ковзання та приведена кривизна. Ці показники відносяться до групи геометро-кінематичних, оскільки залежать від геометрії зубців та кінематики передачі. Їх віднесено до одиничних та вони входять до складу комплексних показників, до яких зазвичай відносять контактну міцність активних поверхонь зубців, стійкість проти заїдання, зносостійкість, товщина масляного шару та питома робота сил тертя. Комплексні показники разом з геометро-кінематичними визначають втрати у зачепленні. Цей показник за своєю суттю $є$ мірою ефективності зачеплення, а за алгоритмом його визначення - інтегральним показником. Встановлено, що у крайніх точках поля зачеплення синусоїдальні передачі мають щонайменше у 10,14 рази більший показник контактної міцності; у 10,13 рази менший показник заїдання; у 21,58 рази менший показник зносу поверхонь зубців шестірні; у 36,81 рази менший показник зносу поверхонь зубців колеса; у 6,57 рази більший показник товщини мастильної плівки; у 8,3 рази меншу питому роботу сил тертя на поверхні зубців шестірні; у 14,16 рази меншу питому роботу сил тертя на поверхні зубців колеса. Втрати у зачепленні синусоїдальної передачі у 2,13 рази менші. Таким чином підтверджено припущення розробника синусоїдального зачеплення Е. Вільдгабера (Ernest Wildhaber) про підвищену навантажувальну здатність, а також попередні результати, отримані першим дослідником цього зачеплення Ю.В. Анікіним. Результати роботи можуть бути використані для подальших експериментальних досліджень, зокрема для вибору рівнів навантаження редукторів при випробуваннях.

Ключові слова: прямозуба передача, опукло-ввігнутий контакт, синусоїдальне зачеплення, показники працездатності

P. Tkach, P. Nosko, O. Bashta, Yu. Tsybrii, O. Revyakina, G. Boyko. Comparison of sinusoidal and involute spur gears by meshing characteristics. The article deals with the relevant task of development of gears, that are alternative to the involute (conventional) ones, and can be applied in power drives of machines. The most common requirement for alternative types of gearing is higher comparing with traditional load capacity and durability. To provide this requirement, a sinusoidal gearing can be used. The purpose of this work is to detect its advantages comparing with conventional transmissions. In order to achieve the goal, the theoretical study of qualitative meshing characteristics, which relate to three levels - single, complex and integral, was performed. For gearings the meshing characteristics are the sliding velocity, the velocity of contact points in normal to the contact line direction, relative sliding and reduced curvature. These characteristics belong to the geometric-kinematic group, because they depend on the teeth geometry and the transmission kinematics. They are classified as single and they form part of complex characteristics, which usually include the surface strength of teeth, resistance to scuffing, wear resistance, the oil film's thickness and the specific work of frictional forces. The complex characteristics, together with geometric-kinematic, determine the gearing power loss. This characteristic is inherently a measure of gearing effectiveness and it is an integral characteristic by its algorithm of definition. It is established that at the extreme points of the line-of-action, the sinusoidal gearing have the characteristic of surface strength at least 10.14 times greater; the characteristic of scuffing at least 10.13 times less; the characteristic of wear of pinion's teeth surfaces at least 21.58 times less; the characteristic of wear of gear's teeth surfaces at least 36.81 times less; the characteristic of oil film's thickness at least 6.57 times more; specific work of frictional forces on the surface of the pinion's teeth at least 8.3 times less; the specific work of frictional forces on the surface of gear in at least 14.16 times less. The gearing power loss of sinusoidal meshing 2.13 times less. Therefore, the assumption of sinusoidal gearing developer Ernest Wildhaber about the increase of load capacity, as well as the previous results obtained by the first researcher of this gearing Yu.V. Anikin, were approved. The results of the work may be used for further experimental studies, in particular, for the reducers' load levels selecting during the experiments.

Keywords: spur gear, convex-concave contact, sinusoidal gearing, meshing characteristics

DOI: 10.15276/opu.1.57.2019.06

(C) 2019 The Authors. This is an open access article under the CC BY license (http://creativecommons.org/licenses/by/4.0/). 
Introduction. The drives based on gears are widely used in all kinds of equipment, both general and special purpose. The characteristics of gearing serviceability, such as load capacity, efficiency, smoothness of work, determine the quality of equipment in general. Therefore, the task of gear drives improvement is certainly relevant. The advanced way to improve gearing is the choice of rational geometry of gearing. This approach has been applied for the involute (conventional) gearing up to the present [ $1-3]$. Since the conventional gearing has practically exhausted the reserves for increasing the load capacity, one of the ways to solve this problem is a search of alternative geometry for gearing. The application of alternative gearing types, in particular, sinusoidal gearing, in which convexconcave contact of active surfaces is realized, has high expectation.

Analysis of recent research and publications. More than half a century ago, the first alternative Wildhaber-Novikov gearings began to develop actively and it was implemented in the industry. They have a convex-concave contact. Since the contact in these gearings is the disadvantage is a small contact ratio. However, the advantages of convex-concave contact have been confirmed by years of research and practice of their application.

Since then, a number of alternative types of gearing with a convex-concave contact of teeth active surfaces have appeared. Moreover, in recent years the researches aimed at creating unconventional gears with convex-concave contact have been carried out actively. This is quite logically, because the new methods of teeth cutting by disc [4,5] or shank-type [6] milling cutter have become available.

The authors of [7] proposed a new type of C-C gearing with the shape of a tooth that implements the convex-concave contact. The tooth shapes are constructed on the basis of line-of-action defined by the arcs, which may be symmetrical or asymmetrical relatively to the pitch point. The comparison of such gears with conventional ones presented in [8] shows the advantages of C-C gears in terms of surface strength and durability.

In [9] analytical dependencies were obtained for determining some characteristics of evolute gearing [10]. As in the C-C gearing, in evolute one the convex-concave linear contact is realized. However, by a contrast to the C-C gearing, the evolute one is based on the more general case of working surfaces synthesis by the line-of-action shape. The last one may be symmetrical or asymmetrical relatively to the pitch point. The indicators of evolute gearing are higher than the conventional ones.

The study [11] is devoted to obtaining the analytical dependencies for determining the meshing characteristics of a conchoidal gearing. The reference profile in such gearing is formed by segments of circle arcs. However, unlike Wildhaber-Novikov's gearings a linear contact is realized in conchoidal gearings and the line-of-action is Nichomed's conchoid. The further studies of such gearings allowed to establish their advantages comparing to the conventional ones.

In addition to the choice of rational geometry and synthesis by the line-of-action, an effective way of gears' improving is a synthesis of reference profile according to the given geometric-kinematic meshing characteristics. Moreover, such synthesis by complex characteristics is also possible for spur gears and this is confirmed by the results of [12]. This study presents recommendations for determining the geometry of gearing with increased wear resistance. In the presented gearings, a convexconcave contact is also realized.

Among the existing alternative gearings, except the above mentioned, a sinusoidal gearing proposed by E. Wildhaber more than half a century ago (US3251236) is of great interest. The author proposed the shape of the teeth profiles providing a high smoothness of work. In a later study by Yu.V. Anikin which was performed under the advising of prof. V.A. Gavrilenko, a lower noise level was confirmed and the possibility of sinusoidal gearing in power drives application was suggested.

The article [13] presents the dependencies for determining the meshing characteristics of sinusoidal gearing, but the values of these characteristics are not defined.

The purpose of this research is to confirm the above-mentioned assumption by a detailed study of the meshing characteristics of sinusoidal gearing and their comparison with the characteristics of conventional gears. 
Materials and Methods. For the qualitative estimation of gearing serviceability, a number of geometric-kinematic indicators can be used, which can be obtained for the sinusoidal gearing based on the results of study [13].

1. Sliding velocity:

$$
V_{S}=\omega_{1}\left(\frac{u+1}{u}\right) h \sin \lambda \sqrt{4 h^{2} \cos ^{2} \lambda+1},
$$

where $\omega_{1}$ is an angular velocity of pinion;

$u$ is a gear ratio;

$h$ is a height of sinusoidal reference profile in

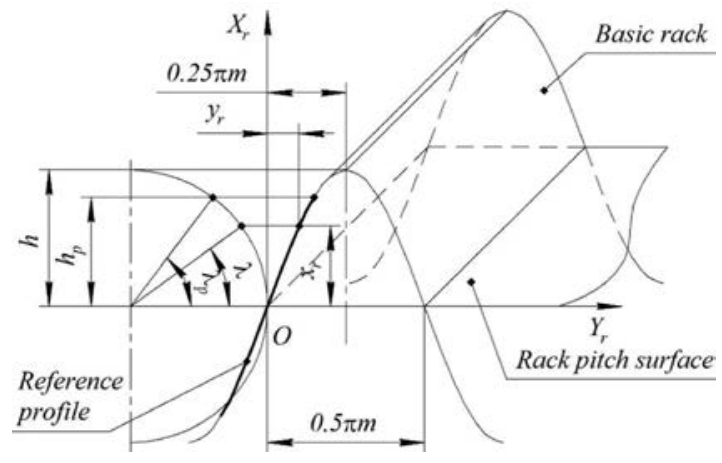

Fig. 1. Basic rack and reference profile of sinusoidal gearing fractions of gearing module $m$. It equals to a radius of the circle which creates the sinusoid (Fig. 1);

$\lambda$ is a parameter for the sinusoid, this angle $\lambda$ varies from 0 to $\lambda_{p}$ for the working part of profile $h_{p}$, from $\lambda_{p}$ to $\pi / 2$ for the root fillet (Fig. 1).

It should be noted that $h$ and $\lambda$ clearly determine the basic rack in the system of coordinates related to the reference profile $x_{r}=h \sin \lambda, y_{r}=\lambda / 2$.

2. The velocity of contact point in the direction normal to the contact line on the pinion's and gear's surfaces:

$$
V_{i}=\omega_{i}\left(\frac{R_{i}}{4 h^{2} \cos 2 \lambda+1} \pm h \sin \lambda\right) \sqrt{4 h^{2} \cos ^{2} \lambda+1}
$$

where $\omega_{i}$ is an angular velocity of pinion $(i=1)$ or gear $(i=2)$, rad/s;

$R_{i}$ is a radius of pinion's ( $i=1$ ) or gear's ( $\left.i=2\right)$ pitch circle in fractions of $m$;

3. The total velocity of contact points:

$$
V_{\Sigma}=\omega_{1}\left[\frac{2 R_{i}}{4 h^{2} \cos 2 \lambda+1}+\left(1-\frac{1}{u}\right) h \sin \lambda\right] \sqrt{4 h^{2} \cos ^{2} \lambda+1} .
$$

4. The specific sliding on the pinion's $(i=1)$ and gear's $(i=2)$ teeth surface:

$$
\eta_{i}= \pm \frac{(u+1)}{u} \cdot \frac{h \sin \lambda\left(4 h^{2} \cos 2 \lambda+1\right)}{R_{i} \pm h \sin \lambda\left(4 h^{2} \cos 2 \lambda+1\right)} .
$$

5. The reduced curvature of working surfaces in the direction perpendicular to the instant contact line:

$$
\chi_{\text {red }}=\frac{\left(R_{1}+R_{2}\right)\left(4 h^{2} \cos 2 \lambda+1\right)^{2}\left(4 h^{2} \cos ^{2} \lambda+1\right)^{-1.5}}{\left[R_{1}+h \sin \lambda\left(4 h^{2} \cos 2 \lambda+1\right)\right]\left[R_{2}-h \sin \lambda\left(4 h^{2} \cos 2 \lambda+1\right)\right]} .
$$

In the equation (2) and (4) the sign “+” is taken for the pinion, and "-” for the gear.

For a more complete estimation of gearing quality the complex meshing characteristics depending on the geometric-kinematic indicators (1) - (5) may be applied.

1 . The surface strength is evaluated based on the assumption that in the result of gearing conformability under the load the surface stresses have constant values. This assumption is usually used in calculations of traditional gearing, because it is consistent well with the experimental results. It was used in study [13] for the determination the relative characteristic of surface strength. If the expression [13] is converted for spur gears it will be obtained:

$$
\Theta_{H}=\frac{h \cos \lambda}{\chi_{\text {red }} \sqrt{h^{2} \cos ^{2} \lambda+0.25}} .
$$


This characteristic is actually the load factor for the surface stresses determine. It contains the geometric parameters of tooth and affects the critically allowable load for the condition of surface strength:

$$
T_{1}=k R_{1} b_{w} \Theta_{H},
$$

where $b_{w}$ is a width of gearing;

$k$ is a proportionality factor;

$$
k=\frac{1}{E_{\text {red }}}\left(\frac{\sigma_{H}}{0.418}\right),
$$

determined from the Hertz equation:

$$
\sigma_{H}=0.418 \sqrt{q_{n} E_{\text {red }} \chi_{\text {red }}},
$$

where $q_{n}$ is a force acting on the unit of length of contact line (directed normally to the working surfaces of the teeth);

$E_{\text {red }}$ is a reduced modulus of elasticity of gears' materials.

Obviously, the critical load corresponds to the limit value of $k_{\max }$ for $\sigma_{H}=\left[\sigma_{H}\right]$. Then, taking into account (8) and (9), the maximum specific force:

$$
q_{n}^{\max }=\frac{k_{\max }}{\chi_{\text {red }}} .
$$

2. The scuffing is usually estimated by the values of teeth working surfaces temperature which is determined by the Block's theory [14]. However, for the comparative evaluation of various gearings the instantaneous flash temperature in the zone of contact [15] based on the Block theory may be used:

$$
\Theta_{S}=\frac{1.84 f q_{n}^{0.75} V_{S} \chi_{\text {red }}^{0.25}}{\left|\sqrt{V_{1}}+\sqrt{V_{2}}\right|} .
$$

The coefficient 1.84 in this equation contains the physical characteristics of gears and oil. Since for comparison we will consider gears made of identical materials and the same oil, we will use a relative characteristic:

$$
\tilde{\Theta}_{S}=\frac{f q_{n}^{0.75} V_{S} \chi_{r e d}^{0.25}}{\sqrt{V_{1}}+\sqrt{V_{2}}} .
$$

In the equation (11) $f$ is the coefficient of sliding friction in the teeth contact zone. It is defined according to [16]:

$$
f=0.09 q_{n}^{0.1}\left[10+\lg \left(\frac{\mathrm{HB} \cdot \mathrm{Ra} \cdot \chi_{\text {red }}}{E_{\text {red }}}\right)\right] \chi_{\text {red }}^{0.25} v^{-0.07} V_{\Sigma}^{-0.1} V_{S}^{-0.35},
$$

where $q_{n}$ is in $\mathrm{kgf} / \mathrm{cm}$;

$E_{\text {red }}$ is in $\mathrm{kg} / \mathrm{sm}^{2}$;

$\chi_{\text {red }}$ is in $1 / \mathrm{cm}$;

$V_{\Sigma}$ and $V_{S}$ is in $\mathrm{cm} / \mathrm{s}$;

HB is a Brinell's hardness number of harder gear's teeth, $\mathrm{kg} / \mathrm{cm}^{2}$;

$\mathrm{Ra}$ is a surface roughness of harder gear's teeth, cm;

$v$ is an oil viscosity, cSt.

The equation (12) is valid under conditions $v \geq 1 \mathrm{cSt} ; q_{n} \geq 300 \mathrm{kgf} / \mathrm{cm} ; V_{\Sigma} \geq 100 \mathrm{~cm} / \mathrm{s}$; $\mathrm{HB}>5000 \mathrm{~kg} / \mathrm{cm}^{2} ; V_{S}>20 \mathrm{~cm} / \mathrm{s} ; 1 / \chi_{\text {red }}>0.5 \mathrm{~cm}$; Ra $>10^{-5} \mathrm{~cm}$. If these conditions are not met, the coefficient of sliding friction is determined by the equation [15]: 


$$
f=\frac{1}{0.008 V \sqrt{v}+0.01 V_{\Sigma} \Phi\left(\sigma_{H}, v\right)+13.4},
$$

where $\Phi\left(\sigma_{H}, v\right)=0.47-0.13 \cdot 10^{-4} \sigma_{H}-0.4 \cdot 10^{-3} v$,

$\sigma_{H}$ is in $\mathrm{kg} / \mathrm{sm}^{2}$.

The parameters' measurement units included in (12) and (13) are given in accordance with [15, 16]. The specific load $q_{n}$ in the equations (11), (12) and (13) taking into account the equations (7) - (9) equals:

$$
q_{n}=\frac{T_{1}}{\chi_{\text {red }} R_{1} \Theta_{H}} .
$$

3. Wear of teeth active surfaces may be estimated by the relative value of wear layer thickness [16]:

$$
h_{w i}=I \Omega \sqrt{\frac{q_{n}}{\chi_{\text {red }}}}\left|\eta_{i}\right|,
$$

where $\Omega$ is a coefficient depending on the lubricant properties, it doesn't take into account the geometry of the teeth;

$I$ is an intensity of surfaces wear, which for the run-in surfaces is determined in accordance with the recommendations of I.V. Kragelsky [16] by the equation:

$$
I=K \sigma_{H} f^{t_{f}},
$$

where $K$ is a coefficient depending on the elastic properties and hardness of gear's material;

$t_{f}$ is a parameter of frictional fatigue curve.

The equation (15) taking into account (9), (14) and (16) may be represented as:

$$
h_{w i}=\frac{0.418 K \Omega T_{1} \sqrt{E_{\text {red }}}}{R_{1}} \cdot \frac{f^{t f}\left|\eta_{i}\right|}{\chi_{\text {red }} \Theta_{H}} .
$$

The relative value of wear:

$$
\tilde{h}_{w i}=\frac{f^{t f}\left|\eta_{i}\right|}{\chi_{\text {red }} \Theta_{H}}
$$

may be used as for a comparative evaluation of gearings with different teeth profiles but made of identical materials and works in identical conditions under the same load

4. The oil film's thickness is determined on the basis of dependence shown in the study [17]:

$$
h_{o}=3.17 \mu_{0}^{0.75} \alpha^{0.6} V_{\Sigma}^{0.75} \chi_{\text {red }}^{-0.4} q_{n}^{-0.15},
$$

where $\mu_{0}$ is a dynamic viscosity of oil at atmospheric pressure;

$\alpha$ is an oil viscosity's piezo coefficient, which depends on the temperature and surface stress in the contact zone of the teeth.

The equation (18), taking into account (14), may be represented as:

$$
h_{o}=3.17 R_{1}^{0.15} T_{1}^{-0.15} \mu_{0}{ }^{0.75} \alpha^{0.6} V_{\Sigma}^{0.75} \chi_{\text {red }}^{-0.25} \Theta_{H}^{0.15} .
$$

The relative value of oil film's thickness obtained from (19) after excluding parameters that don't depend on the teeth geometry:

$$
\tilde{h}_{o}=V_{\Sigma}^{0.75} \chi_{\text {red }}^{-0.25} \Theta_{H}^{0.15}
$$

can be used for the comparative evaluation of gearing with different teeth profiles.

5. The specific work of frictional forces on the contact line area of unit length is determined by the equation [15]:

$$
d A_{f i}=q_{n} f\left|\eta_{i}\right|
$$


According to the results of work [13], the gearing power loss is an integral characteristic, based on the geometric-kinematic (1) and complex (6) characteristic as well as specific load (14). It is defined as:

$$
\psi_{m}=\frac{b_{w} R_{1}}{\pi \omega_{1} T_{1}} \int_{\varphi 10}^{\varphi 20} q_{n} f V_{S} d \varphi,
$$

where $\varphi_{10}, \varphi_{20}$ is the pinion's turning angles, that correspond to the starting and end of the gearing.

Correspondence of pinion's turning angle with the position of contact line on the profile is determined from the equation [18]:

$$
\varphi=\frac{h^{2} \sin 2 \lambda+0.5 \lambda}{R_{1}} .
$$

The bending strength of sinusoidal tooth in the first approximation was evaluated in [19]. Its results are in good agreement with the assumption of Yu.V. Anikin [20] about the sinusoidal tooth's advantages. However, a more detailed estimation of stress state of sinusoidal teeth is quite huge and complex task, so it should be extract in an independent study.

So, the geometric-kinematic (1) - (5), complex (6), (11), (17), (20), (21), as well as integral (22) characteristics was applied for comparison of sinusoidal gearing with conventional one. The geometrickinematic meshing characteristics of conventional gearing were determined using the formulas of [21]. It may be applied because quasi-involute arc or crowded gear have the involute spur gearing in a midsection. The dependence of $\varphi$ on the contact line position for the conventional gearing is also determined by [21]. For comparison, we choose gearings with the parameters presented in the Table 1.

Table 1

Output for gearing comparison

\begin{tabular}{l|c|c|c}
\hline \multicolumn{1}{c|}{ Parameter } & Designation & Units & Value \\
\hline Gearing Module & $m$ & $\mathrm{~mm}$ & 10 \\
\hline Number of Pinion's Teeth & $z_{1}$ & & 100 \\
\hline Number of Gear's Teeth & $z_{2}$ & & 1.25 \\
\hline Addendum and Dedendum Coefficients of Involute Tooth & $h_{a}, h_{f}$ & & 1.37 \\
\hline Addendum Coefficient of Sinusoidal Tooth & $h_{p}$ & \multicolumn{2}{c}{20} \\
\hline Pressure Angle & $\alpha$ & $\mathrm{kg} / \mathrm{cm}^{2}$ & $25000^{*}$ \\
\hline Brinell Hardness of Teeth Working Surfaces & $\mathrm{HB}$ & $0.00032^{*}$ \\
\hline Roughness of Working Surfaces & $\mathrm{Ra}$ & $2141404^{*}$ \\
\hline Materials Modulus of Elasticity & $E_{\text {red }}$ & $\mathrm{kg} / \mathrm{cm}^{2}$ & 20 \\
\hline Oil's Viscosity & $v$ & $\mathrm{cSt}$ & $20^{*}$ \\
\hline Torque on the Pinion Shaft & $T_{1}$ & $\mathrm{kgf} \cdot \mathrm{m}$ & $12730^{*}$ \\
\hline Angular Velocity of Pinion & $\omega_{1}$ & $\mathrm{rad} / \mathrm{s}$ & 150 \\
\hline Parameter of Friction Fatigue Curve & $t_{f}$ & & 2 \\
\hline
\end{tabular}

Results and Discussion. Geometric-kinematic characteristics of both gearings are presented in Fig. $2-5$ and complex characteristics are presented in Fig. 6 - 12. The solid and dashed lines correspond to sinusoidal and conventional gearing respectively.

\footnotetext{
*Values are given in units for calculations by equations from [15]
} 


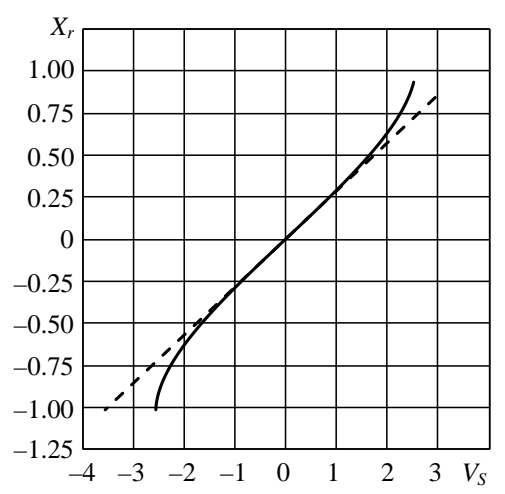

Fig. 2. Sliding velocity*

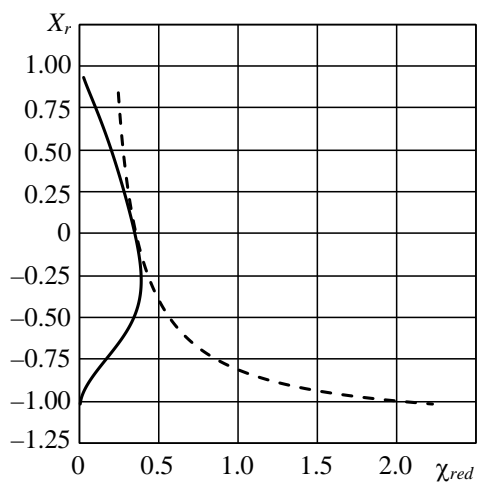

Fig. 5. Reduced curvature

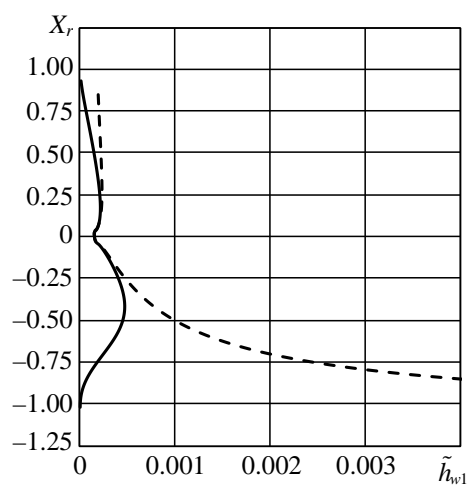

Fig. 8. Relative characteristic of pinion's teeth wear

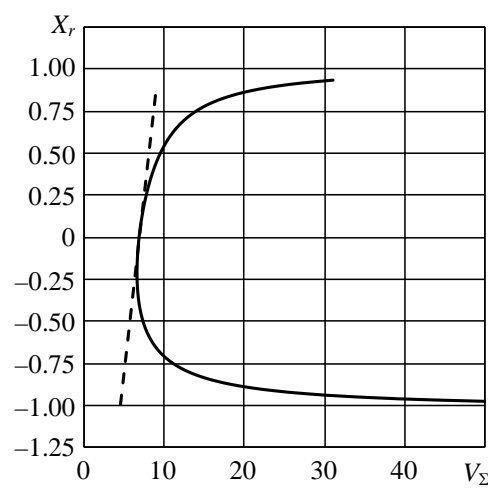

Fig. 3. Total velocity of contact points

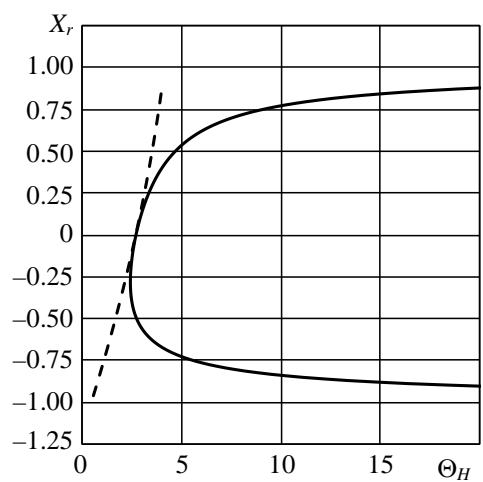

Fig. 6. Relative characteristic of surface strength

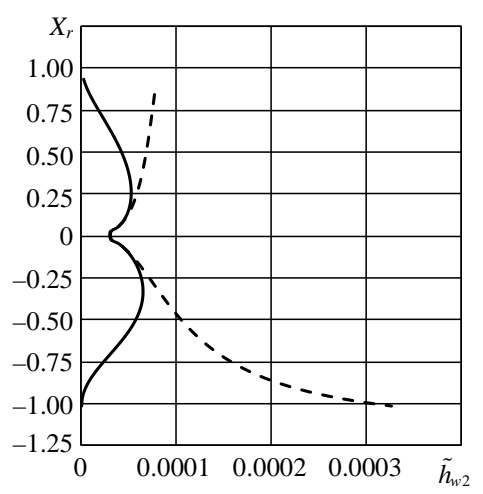

Fig. 9. Relative characteristic of gear's teeth wear

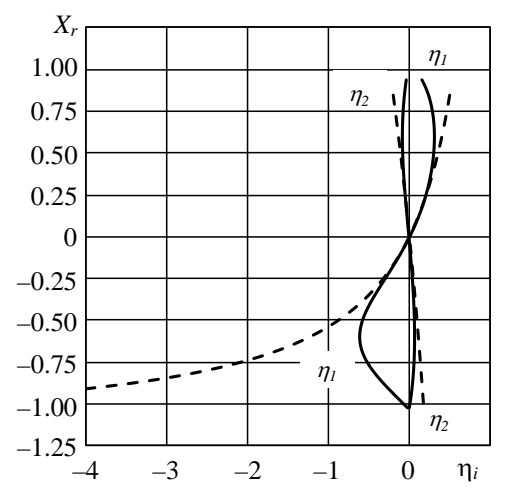

Fig. 4. Specific sliding

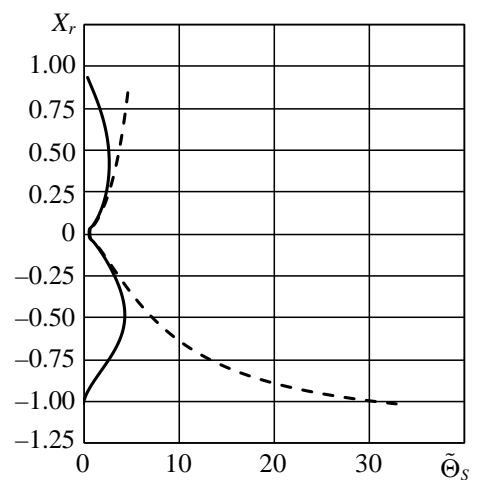

Fig. 7. Relative characteristics of scuffing

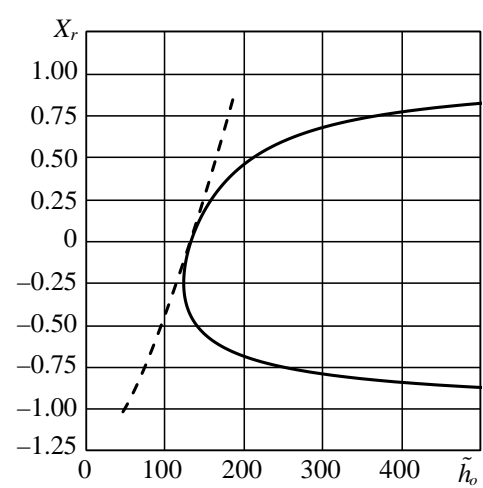

Fig. 10. Relative characteristic of oil's film thickness

* 1. An ordinate axis on Fig. 2 - 12 displays the whole depth of basic rack profile

2. The positive value of ordinate axis $x_{r}$ for $V_{S}, V_{\Sigma}, \chi_{\text {red }}, \Theta_{H}, \tilde{\Theta}_{S}$ and $\tilde{h}_{o}$ corresponds to the pinion's addendum and gear's dedendum (end of meshing). The negative value of ordinate axis for these characteristics corresponds to pinion's dedendum and gear's addendum (starting of meshing)

3. The positive and negative values of ordinate axis $x_{r}$ for $\eta_{1}, \tilde{h}_{w 1}, d A_{f 1}$ correspond to the pinion's addendum and pinion's dedendum respectively

4. The positive and negative values of ordinate axis $x_{r}$ for $\eta_{2}, \tilde{h}_{w 2}, d A_{f 2}$ correspond to the gear's addendum and gear's dedendum respectively

5. The values of velocities $V_{S}$ and $V_{\Sigma}$ was defined for $\omega_{1}=1 \mathrm{rad} / \mathrm{s}$ 


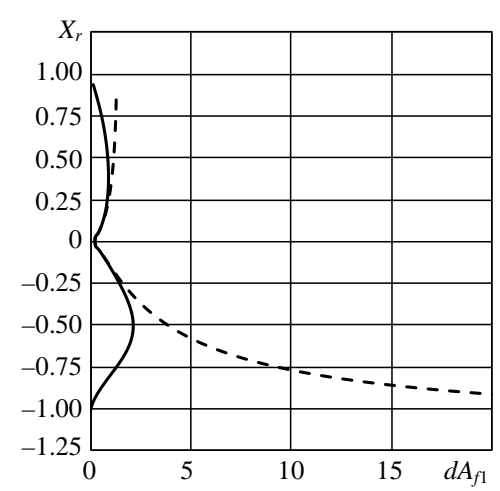

Fig. 11. Specific work of frictional forces on pinion's teeth surfaces

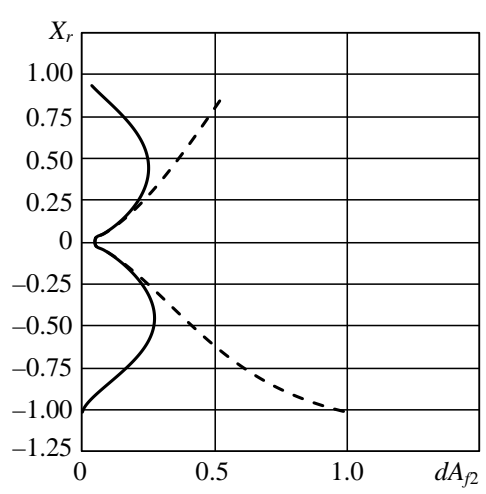

Fig. 12. Specific work of frictional forces on gear's teeth surfaces

The coordinates $x_{r}$ which correspond to the starting and end points of gearing was defined with accordance to recommendations of [18] and [21] for sinusoidal and conventional gearing respectively.

Table 2

Comparison of meshing characteristics' values

\begin{tabular}{|c|c|c|c|c|c|c|c|}
\hline Geometric-kinematic characteristics at & $\frac{V_{S}^{\text {inv }}}{V_{S}^{\sin }}$ & $\frac{V_{1}^{\sin }}{V_{1}^{\text {inv }}}$ & $\frac{V_{2}^{\sin }}{V_{2}^{\text {inv }}}$ & $\frac{V_{\Sigma}^{\sin }}{V_{\Sigma}^{\text {inv }}}$ & $\frac{\eta_{1}^{\text {inv }}}{\eta_{1}^{\sin }}$ & $\frac{\eta_{2}^{\text {inv }}}{\eta_{2}^{\sin }}$ & $\frac{\chi_{\text {red }}^{\text {inv }}}{\chi_{\text {red }}^{\text {sin }}}$ \\
\hline - the end point of gearing & 1.18 & 2.85 & 4.86 & 3.52 & 3.35 & 5.72 & 10.65 \\
\hline - the pitch point zone & 1 & 1 & 1 & 1 & 1 & 1 & 1 \\
\hline - the starting point of gearing & 1.4 & 206.82 & 24.23 & 42.92 & 288.86 & 33.84 & 3587.7 \\
\hline \multirow{2}{*}{ Complex characteristics at } & $\Theta_{H}^{\sin }$ & $\Theta_{S}^{i n v}$ & $\underline{h}_{w 1}^{i n v}$ & $\underline{h_{w 2}^{i n v}}$ & $h_{0}^{\sin }$ & $d A_{f 1}^{i n v}$ & $d A_{f 2}^{i n v}$ \\
\hline & $\overline{\Theta_{H}^{i n v}}$ & $\Theta_{S}^{\sin }$ & $h_{w 1}^{\sin }$ & $h_{w 2}^{\sin }$ & $\overline{h_{o}^{i n v}}$ & $d A_{f 1}^{\sin }$ & $d A_{f 2}^{\sin }$ \\
\hline - the end point of gearing & 10.14 & 10.13 & 21.58 & 36.81 & 6.57 & 8.3 & 14.16 \\
\hline - the pitch point zone & 1 & 1 & 1 & 1 & 1 & 1 & 1 \\
\hline - the starting point of gearing & 3353 & 2671 & 341491 & 40002 & 438.57 & 9601.4 & 1124.71 \\
\hline
\end{tabular}

Analysis of Table 2 shows that both transmissions have the same values in the near-pitch zone. This fact is due to two reasons. Firstly, the curvature of the sinusoidal reference profile on the pitch line according to the results of $[18,20]$ equals zero. It means that at the pitch point the sinusoidal gearing has meshing characteristics of the involute one. Secondly, the profile angle of the sinusoidal reference profile on the pitch line is $20^{\circ}$ (Table 1 ).

The geometric-kinematic characteristics of sinusoidal gear at the end point of gearing are 1.18...10.65 times better. Complex characteristics are 6.57...36.81 times better.

The most of sinusoidal gear's characteristics at the beginning of the gearing are much better. This fact is due to the dependence of complex characteristics on reduced curvature and specific sliding. The beginning of the gearing takes place at the lowest point of the pinion's tooth profile where the values of reduced curvature and specific slides of involute gears are usually high. On the contrary, both of characteristics of sinusoidal gearing have very low values at the beginning of gearing.

The gearing power loss, defined by formula (22), have the following values:

$-\Psi_{m}^{i n v}=0.01$ for conventional gearing;

$-\Psi_{m}^{\mathrm{sin}}=0.0047$ for sinusoidal gearing.

It should be noted that the value of gearing power loss calculated taking into account the value of $V_{\Sigma}$ by the recommendations of [15] equals 0.011 . Consequently, the formula (22) is in good correlation with formula of [15]. So, sinusoidal gearing has an advantage of 2.13 times by an integral characteristic. 


\section{Conclusions}

1. As a result of the definition and analysis of meshing characteristics, the advantages of sinusoidal gearing over the traditional one are determined. Thus, using the theoretical methods the assumption of previous researchers about the possibility of using of sinusoidal gears in power transmissions was confirmed.

2. The greatest advantages of sinusoidal gears, up to 5 orders of magnitude, occur at the beginning of the gearing. They are caused by almost zero values of the reduced curvature and specific sliding of the sinusoidal gearing, and the high values of these characteristics in the conventional gearing. At the pitch point, both of transmissions have the same values of characteristics. At the end of the gearing, the complex characteristics of sinusoidal gearing are $6.57 . .36 .81$ times better.

3. The gearing power loss was considered as an integral characteristic. The sinusoidal gearing's power loss is in 2.13 times less than involute's one. It shows not only the higher energy efficiency, but also the better combination of values of geometric-kinematic and complex characteristics of sinusoidal gearing.

4. The results of this work may be used for further experimental research. Particularly, in the reducers' tests for determination of the load levels using the formulas (6) - (10).

\section{Література}

1. Попов А.П., Кипреев Ю.Н. Повышение нагрузочной способности зубчатых передач по контактным напряжениям. Вестник Наи. техн. ун-та «ХПИ» : сб. науч. тр. Темат. вып.: Проблемы механического привода. 2009. № 20. С. 108-117.

2. Бабичев Д.Т., Смовж А.И., Кривошея А.В. Синтез современных цилиндрических прямозубых эвольвентных передач в курсе «Прикладная механика». Збірник наукових праць «Вісник НТУ «ХПІ». Серія: Проблеми механічного приводу. 2015. № 35. С. 10-19.

3. Amani A., Spitas C., Spitas V. Generalized non-dimensional multi-parametric involute spur gear design model considering manufacturability and geometrical compatibility. Mechanism and Machine Theory. 2017. № 109. Р. 250-277.

4. Грицай І.Є., Вільшанецький В. І. Удосконалення технології виготовлення зубчастих коліс на основі нового методу зубонарізання. Вісник Нац. техн. ун-ту «ХПІ»: зб. наук. пр. Темат. вип.: Проблеми механічного приводу. 2011. № 28. С. 44-52.

5. Експериментальне дослідження контурної обробки циліндричних зубчастих коліс дисковим інструментом / С. І. Пастернак та ін. Вісник Нац. техн. ун-ту «ХПІ»: зб. наук. пр. Темат. вип.: Проблеми механічного приводу. 2010. № 26. С. 94-101.

6. Формирование конических зубьев с циклическим продольным профилем на универсальных многокоординатных станках с ЧПУ / В. Н. Стрельников и др. Вестник Нац. техн. ун-та «ХПИ»: сб. науч. тр. Темат. вып.: Проблемы механического привода. 2009. № 20. С. 163-171.

7. Tököly P., Gajdoš M., Bošanský M. Effect of tooth shape to size of contact stress noninvolute gearing. Вестник Наи. техн. ун-та «ХПИ»: сб. науч. тр. Темат. вып.: Проблемы механического привода. 2009. № 19. C. 10-20.

8. Kopilakova B., Bosansky M., Petrak L. Comparison HRC and C-C gearing for damage to pitting. Bulletin of National Technical University "KhPI”: coll. of sci. papers. Ser.: Problem of mechanical drive. 2016. № 23 (1195). P. 77-81.

9. Павлов А.И., Павлов В.А., Протасов Р.В. Определение характеристик в зацеплении зубчатых колес, нарезаемых методом обката. Вестник Нац. техн. ун-та «ХПИ»: сб. науч. тр. Темат. вып.: Проблемы механического привода. 2009. № 19. С. 111-117.

10. Носко П.Л., Павлов А.И., Вербицкий В.И. Геометрический метод создания зубчатых зацеплений. Вестник Наи. техн. ун-та «ХПИ»: сб. науч. тр. Темат. вып.: Проблемы механического привода. 2012. № 35. C. 113-116.

11. Скляр Ю.А. Геометрокинематические критерии прямозубых конхоидальных передач со смещением исходного контура. Вестник Нач. техн. ун-та «ХПИ»: сб. науч. тр. Темат. вып.: Проблемы механического привода. 2010. № 27. С. 162-166.

12. Основи синтезу вихідного контуру циліндричних зубчастих передач із підвищеною зносостійкістю зубців коліс / В. П. Шишов и др. Вестник Нац. техн. ун-та «ХПИ»: сб. науч. тр. Темат. вып.: Проблемы механического привода. 2009. № 20. С. 171-176. 
13. Якісні показники працездатності синусоїдальних циліндричних прямозубих передач / П. М. Ткач та ін. Вісник Нац. техн. ун-ту «ХПІ»: зб. наук. пр. Сер.: Проблеми механічного приводу. 2017. № 25 (1247). C. 135-139.

14. Blok H. Measurements of temperature flashes on gear teeth under extreme pressure conditions. Proc. Gen. Disc. Lubricating. 1937. Vol. 11, P. 14-20.

15. Кудрявцев В.Н., Державец Ю.А., Глухарев Е.Г. Конструкции и расчет зубчатых редукторов. Л.: Машиностроение, 1971. $328 \mathrm{c.}$

16. Трение, изнашивание и смазка. Справочник. В 2-х кн. / Под ред. И.В. Крагельского и В.В. Алисина. М. : Машиностроение, 1978. 400 с.

17. Коднир Д.С. Контактная гидродинамика смазки деталей машин. М.: Машиностроение, 1976. 303 с.

18. Ткач П.М. Виробна поверхня та верстатне зачеплення циліндричних прямозубих синусоїдальних передач. Вісник НТУУ «КПІ». Серія: Машинобудування. 2014. № 1(70). С. 112 - 121.

19. Ткач П.М. Попередня оцінка згинальної міцності прямого зуба з синусоїдальним профілем. Вісник Східноукраӥнського національного університету імені Володимира Даля. 2014. № 4(211), Ч. 1. С. $236-241$.

20. Аникин Ю.В. Синусоидальное зацепление: основы геометро-кинематической теории. Воронеж: Изд-во Воронежского ун-та, 1975. 63 с.

21. Геометрокинематические критерии работоспособности цилиндрических квазиэвольвентных передач с арочными и корсетными зубьями / В. П. Шишов и др. Вісник Східноукр. наи. ун-ту ім. В. Даля. 2003. № 12 (70). С. 52-55.

\section{References}

1. Popov, A.P., Kypreev, Yu.N. (2009). Increase of load capacity of gearing under surface stresses. Bulletin of Nat. tech. un. KhPI: Collection of scientific works. Topic: Problems of mechanical drive, 20, 108-117.

2. Babichev, D.T., Smovzh, A.I., \& Krivoshey, A.V. (2015). Synthesis of modern involute spur gears in the course "Applied Mechanics". Bulletin of Nat. tech. un. KhPI: Collection of scientific works. Topic: Problems of mechanical drive, 35, $10-19$.

3. Amani, A., Spitas, C., \& Spitas, V. (2017). Generalised non-dimensional multi-parametric involute spur gear design model considering manufacturability and geometrical compatibility. Mechanism and Machine Theory, 109, 250-277.

4. Gritsay, I. Y., \& Vilshanetskii, V. I. (2011). Improving the technology of gears manufacturing on the basis of new gear cutting method. Bulletin of Nat. tech. un. KhPI: Collection of scientific works. Topic: Problems of mechanical drive, 28, 44-52.

5. Pasternak, S.I. et al. (2010). Experimental study of cylindrical gear contour processing by the disk tool. Bulletin of Nat. tech. un. KhPI: Collection of scientific works. Topic: Problems of mechanical drive, 26, 94-101.

6. Strelnikov V.N. et al. (2009). Formation of bevel gear with a cyclic profile elevation on universal multicoordinate machine tools with CNC. Bulletin of Nat. tech. un. KhPI: Collection of scientific works. Topic: Problems of mechanical drive, 20, 163-171.

7. Tököly, P., Gajdoš, M., \& Bošanský, M. (2009). Effect of tooth shape to size of contact stress noninvolute gearing. Bulletin of Nat. tech. un. KhPI: Collection of scientific works. Topic: Problems of mechanical drive, 19, 10-20.

8. Kopilakova, B., Bosansky, M., \& Petrak, L. (2016). Comparison HRC and C-C gearing for damage to pitting. Bulletin of Nat. tech. un. KhPI: Collection of scientific works. Topic: Problems of mechanical drive, 23(1195), 77-81.

9. Pavlov, A.I., Pavlov, V.A., \& Protasov, R.V. (2009). Definition of meshing characteristics in gears cut by the rotation method. Bulletin of Nat. tech. un. KhPI: Collection of scientific works. Topic: Problems of mechanical drive, 19, 111-117.

10. Nosko, P.L., Pavlov, A.I., \& Verbitsky, V.I. (2012). The geometric method of gears creation. Bulletin of Nat. tech. un. KhPI: Collection of scientific works. Topic: Problems of mechanical drive, 35, 113-116.

11. Sklyar, Yu.A. (2010). Geometric-kinematic criteria of conchoidal spur gears with profile shifting. Bulletin of Nat. tech. un. KhPI: Collection of scientific works. Topic: Problems of mechanical drive, 27, 162-166.

12. Shishov, V.P. et al. (2009). Fundamentals of synthesis of profile for cylindrical gears with increased teeth wear resistance. Bulletin of Nat. tech. un. KhPI: Collection of scientific works. Topic: Problems of mechanical drive, 20, 171-176. 
13. Tkach, P. M. et al. (2017). Qualitative serviceability characteristics of sinusoidal spur gears. Bulletin of Nat. tech. un. KhPI: Collection of scientific works. Topic: Problems of mechanical drive, 25 (1247), 135-139.

14. Blok, H. (1937). Measurements of temperature flashes on gear teeth under extreme pressure conditions. Proc. Gen. Disc. Lubricating, 11, 14-20.

15. Kudrjavcev V.N., Derzhavec Ju.A., \& Gluharev E.G. (1971). Design and calculation of gear reducers. Leningrad: Machinebuilding.

16. Kragel'sky, I.V., \& Alisin, V.V. (1978). Friction, wear and lubrication. Handbook in 2 books. Moscow: Machine Building Publ.

17. Kodnir D.S. (1976). Contact hydrodynamics of lubrication in machine elements. Moscow: Machine Building Publ.

18. Tkach, P.M. (2014). Producing surface and producing gearing of sinusoidal spur gearings. Bulletin of Nat. tech. un. of Ukraine KPI: Series: Machine building, 1(70), 112-121.

19. Tkach, P.M. (2014). Preliminary estimation of bending strength of spur rack tooth with sinusoidal profile. Bulletin of the Volodymyr Dahl East-Ukrainian National University, 4(211), 236-241.

20. Anikin, Yu.V. (1975). Sinusoidal Gearing: Fundamentals of Geometric-Kinematic Theory. Voronezh: Publishing House of Voronezh University.

21. Shishov, V.P., et al. (2003). Geometric-kinematic criteria for the workability of cylindrical quasiinvolute gears with arch and crowded teeth. Bulletin of the Volodymyr Dahl East-Ukrainian National University, 12(70), 52-55.

Ткач Павло Миколайович; Tkach Pavlo, ORCID https://orcid.org/0000-0002-1069-4128

Носко Павло Леонідович; Nosko Pavlo, ORCID: https://orcid.org/0000-0003-4792-6460

Башта Олександр Васильович; Bashta Oleksandr, ORCID: https://orcid.org/0000-0001-7914-897X

Цибрій Юрій Олександрович; Tsybrii Yurii, ORCID: https://orcid.org/0000-0002-7444-6035

Ревякіна Ольга Олександрівна; Revyakina Olha, ORCID: https://orcid.org/0000-0003-4935-3029

Бойко Григорій Олексійович; Boyko Grigory, ORCID: https://orcid.org/000-0001-5065-3200 